\title{
A revision of tetrapod footprints from the late Carboniferous of the West Midlands, UK
}

\author{
Luke E Meade ${ }^{\text {Corresp., }}{ }^{1}$, Andrew S Jones ${ }^{1}$, Richard Butler Corresp. 1 \\ ${ }^{1}$ School of Geography, Earth and Environmental Sciences, University of Birmingham, Birmingham, United Kingdom \\ Corresponding Authors: Luke E Meade, Richard Butler \\ Email address: luke.edward.meade@gmail.com, r.butler.1@bham.ac.uk
}

A series of sandstone slabs from Hamstead, Birmingham (West Midlands, UK), preserve an assemblage of tetrapod trackways and individual tracks from the Enville Member of the Salop Formation (late Carboniferous: late Moscovian-Kasimovian). This material has received limited previous study, despite being one of the few British sites to preserve Carboniferous tetrapod footprints. Here, we restudy and revise the taxonomy of this material, and document it using 3D models produced using photogrammetry. The assemblage is dominated by large tracks assigned to Limnopus isp., which were made by early amphibians (temnospondyls). A number of similar but smaller tracks are assigned to Batrachichnus salamandroides (also made by temnospondyls). Dimetropus leisnerianus (made by early synapsids) and Dromopus lacertoides (made by lizard-like sauropsids such as araeoscelids) are also present. This ichnofauna contrasts with a slightly stratigraphically older, more extensive and better-studied assemblage from Alveley (Shropshire), which is dominated by small amphibians with relatively rare reptiliomorphs, but which lacks Dromopus tracks. The presence of Dromopus lacertoides at Hamstead is consistent with the trend towards increasing aridity through the late Carboniferous. It is possible that the assemblage is the stratigraphically oldest occurrence of this important amniote ichnotaxon. 
1 A revision of tetrapod footprints from the late Carboniferous of the West Midlands, UK

3 Luke E. Meade*, Andrew S. Jones \& Richard J. Butler

4 School of Geography, Earth and Environmental Sciences, University of Birmingham, Edgbaston,

5 Birmingham, B15 2TT, UK

6

7

8

9

10

11

12

13

14

15

16

17

18

19

Peer] reviewing PDF | (2016:09:13333:1:0:NEW 21 Oct 2016) 


\section{Abstract}

22 A series of sandstone slabs from Hamstead, Birmingham (West Midlands, UK), preserve an assemblage of tetrapod trackways and individual tracks from the Enville Member of the Salop Formation (late Carboniferous: late Moscovian-Kasimovian). This material has received limited previous study, despite being one of the few British sites to preserve Carboniferous tetrapod footprints. Here, we restudy and revise the taxonomy of this material, and document it using 3D models produced using photogrammetry. The assemblage is dominated by large tracks assigned to Limnopus isp., which were made by early amphibians (temnospondyls). A number of similar but smaller tracks are assigned to Batrachichnus salamandroides (also made by temnospondyls). Dimetropus leisnerianus (made by early synapsids) and Dromopus lacertoides (made by lizardlike sauropsids such as araeoscelids) are also present. This ichnofauna contrasts with a slightly stratigraphically older, more extensive and better-studied assemblage from Alveley (Shropshire), which is dominated by small amphibians with relatively rare reptiliomorphs, but which lacks Dromopus tracks. The presence of Dromopus lacertoides at Hamstead is consistent with the trend towards increasing aridity through the late Carboniferous. It is possible that the assemblage is the stratigraphically oldest occurrence of this important amniote ichnotaxon. 


\section{INTRODUCTION}

44 In 1912, in a paper presented to the Geological Society of London, Walter Henry Hardaker

45

46

47

48

49

50

51

52

53

54

55

56

57

58

59

60

61 described fossils, including a series of tetrapod footprints and trackways, from what were then considered Permian rocks near Birmingham in the British Midlands. Hardaker was a local school teacher and amateur field botanist who had studied at the nearby University of Birmingham (Andrews, 1973). He had discovered the footprints at New Quarry, in what was then the village of Hamstead, northwest of the city of Birmingham (Fig. 1). Today, the strata yielding these fossils fall within the metropolitan borough of Birmingham, but New Quarry itself has since been filled in. The fossils collected by Hardaker are housed in the collections of the University of Birmingham's Lapworth Museum of Geology (BIRUG) and the Birmingham City Museum and Art Gallery (BMAG).

4 Hardaker (1912) documented similarities between the tracks from Hamstead and those described by Pabst (1908) from the Upper Rotliegend Group (lower Permian) of Thuringia, Germany. Hardaker identified six footprint morphotypes that he assigned to different ichnospecies within Pabst's ichnogenus Ichnium. Hardaker used the similarities between the Hamstead and German footprints to argue for a lower Permian age for the beds exposed at Hamstead; however, subsequent stratigraphic work has assigned the Hamstead deposits to the Enville Member of the Salop Formation. The Salop Formation is dated as late Carboniferous on the basis of macrofloral remains (Besly \& Cleal, 1997). 
62

63

The taxonomy of the Hamstead footprints was partially revised by Haubold \& Sarjeant (1973, 1974). They reassigned five of the six footprint types that Hardaker had assigned to Ichnium to alternative ichnogenera. The ichnospecies Ichniotherium cottae, Dimetropus leisnerianus and Dromopus lacertoides were identified based upon re-examination of the original material whilst Gilmoreichnus brachydactylus and Anthichnium salamandroides were tentatively identified based upon Hardaker's illustrations. Subsequently, the Hamstead tracks were briefly revisited as part of a $\mathrm{PhD}$ thesis by Tucker (2003). She found no evidence for the presence of Ichniotherium cottae, but identified instead Limnopus (Limnopus) vagus, Limnopus (Batrachichnus) salmandroides (recombination of Anthichnium salamandroides), Hyloidichnus bifurcatus (reidentification of Gilmoreichnus brachydactylus), Dimetropus leisnerianus, and Dromopus lacertoides. However, she provided only one figure of the material, and did not discuss the rationale behind the revised identifications.

Tetrapod ichnofaunal localities are rare in the late Carboniferous of the UK. The most extensive and most thoroughly studied assemblage of late Carboniferous footprints comes from the Alveley Member of the Salop Formation at Alveley, southern Shropshire (Haubold \& Sarjeant, 1973, 1974; Tucker \& Smith, 2004). A small number of other localities in the Midlands and Somerset (Haubold \& Sarjeant, 1973, 1974; Milner, 1994) have also yielded tetrapod footprints. Because of this scarcity, we here provide a redescription and reassessment of the Hamstead footprints and make comparisons to other late Carboniferous ichnofaunas, particularly that from Alveley. We discuss the implications for understanding tetrapod evolution through the late Carboniferous, an interval of major floral and faunal turnover dubbed the 'Carboniferous Rainforest Collapse' (Sahney, Benton \& Falcon-Lang, 2010). 
85

86

87

88

89

90

91

92

93

94

\section{Geological Setting}

The material from New Quarry, Hamstead, revised here was collected from sandstones in the upper part of the Enville Member (formerly referred to as the Enville Beds or Enville Formation) of the Salop Formation (Warwickshire Group). Reaching a thickness of 100-247m (Powell et al., 2000) in the West Midlands, the Enville Member has been proposed to be of Westphalian D to Stephanian age within regional European stratigraphy (Waters, Glover \& Powell, 1994; Glover \& Powell, 1996; Johnson, Glover \& Turner, 1997; Besly \& Cleal, 1997; Powell et al., 2000), which correlates to the late Moscovian to Kasimovian of the global Carboniferous stratigraphy (Gradstein et al., 2012). The Enville Member is the upper of the two members of the Salop Formation, the other being the Alveley Member (formerly Keele Formation), the source of the Alveley track assemblage (Haubold \& Sarjeant, 1973, 1974; Tucker \& Smith, 2004).

6

The Enville Member comprises interbedded red mudstones and red-brown fine-coarse grained, locally pebbly sandstones which are mostly sublitharenite (Waters, Glover \& Powell, 1994; Glover \& Powell, 1996; Johnson, Glover \& Turner, 1997). Lenticular beds of conglomerate, the clasts of which consist mostly of Carboniferous limestone and chert, are also present. The depositional environment of the Enville Member is considered to have been a welldrained fluvially dominated plain (Besly, 1988), being a slightly more arid environment with more sporadic fluvial deposition than in the underlying Alveley Member (Glover \& Powell, 1996).

Within New Quarry, Hardaker (1912) noted the strata to be predominantly obscurely bedded purple marls which alternated irregularly with massive beds of red and green calcareous sandstone, all of which dipped south-east at $3^{\circ}-4^{\circ}$. Many of these sandstone beds were described as lenticular, inconsistent in character, with an undulating and irregular surface. Hardaker also 
108 observed a bed of massive conglomerate of variable thickness at the top of the New Quarry

109 succession, with an unconformity separating it from the underlying beds. The footprint-bearing

110 slabs collected by Hardaker were mostly found as loose blocks of sandstone, with a few being

111 sourced in situ on the lower surfaces of sandstone beds, and were all identified as derived from

112 the 7.5 metres of marls and sandstones (referred to by Hardaker as the 'New-Quarry Marl Sub-

113 group') below the massive conglomerate. The fossils appear to have come from multiple levels

114 within this sequence, rather than a single bed.

\section{Materials and Methodology}

117 The material from Hamstead consists of 15 whole slabs (containing specimens BIRUG BU5268118 5271, BU5274, BU5277-BU5280, BU5282-BU5286, and BMAG 19/14) and four slabs that

119 have each broken into two pieces (containing specimens BIRUG BU3294, BU5267, BU5272, BU5273, BU5275, BU5276, and BU5281). Specimen numbers with BIRUG BU prefixes used

121 here refer to either individual tracks or to trackways (when preserved), rather than to slabs. The slabs themselves have a separate numbering system (see Supplementary Information for further details). Two of the whole slabs (BIRUG BU5287 and BU5288) only preserve arthropod tracks and were not restudied. All tracks are preserved as convex hyporelief on the undersurfaces of red sandstone slabs, and many slabs also include raindrop impressions and/or desiccation cracks. modelling in order to document the trackways and identify new data on trackway dimensions and morphology. Each slab (or multiple slabs if clearly originally connected to one another) was artificially lit and 30-100 photographs were taken at a range of heights following circular paths 
130 around the specimen. Photographs were taken using a tripod-mounted digital SLR camera

131 (Nikon D5100) with a fixed Nikon 50mm lens. This ensured even coverage of the entire

132 specimen.

133

The photographs were imported into the software package Agisoft Photoscan 1.2.4

134 (Professional Edition), which uses automated point picking and triangulation of point clouds to

135 produce high-resolution 3D meshes. All meshes are available for download at

136 https://doi.org/10.5281/zenodo.154382. The meshes were exported as .ply files into the freeware

137 software package CloudCompare 2.7, which was used to visualise the models. These included

138 digital 3D reliefs with coloured contour intervals (methodology from Romilio \& Salisbury,

139 2014), and also reliefs with steep gradients (i.e. the edges of a footprint) brightly highlighted.

140 These relief images are also available at the above link.

141 A summary of the former and revised taxonomic identifications is presented in Table 1 142 and Supplementary Information.

\section{Systematic Palaeoichnology}

Limnopus isp. Marsh, 1894 (Fig. 2 and Fig. 4)

Referred material: BIRUG BU5267, manus and partial pes (Fig. 2A-C); BIRUG BU5268, single

149 pes; BIRUG BU5270, poorly preserved partial manus and partial pes; BIRUG BU5271, four pes

150 prints and several associated poorly preserved manus prints, arranged in a poorly preserved 
151 trackway; BIRUG BU5272, partial pes; BIRUG BU5278, manus and partial pes (Fig. 4); BIRUG

152 BU5284, manus-pes pair (Haubold \& Sarjeant 1973: plate v, fig. 1; Fig. 2D-E); BIRUG

153 BU5286, single manus; BMAG 19/14, single pes.

Description: Tetradactyl and plantigrade to semi-digitigrade manus varying greatly in size and reaching relatively large size for the ichnogenus. Manus width (45-121 mm) always greater than length $(27-90 \mathrm{~mm})$ where both can be measured with confidence. Digits are distinct, broad, and short with rounded ends. Digit III is the longest (16-35 mm), digit I the shortest (13-24 mm), with II and IV being intermediate and similar in length (17-30 $\mathrm{mm}$ and 17-29 $\mathrm{mm}$ respectively). Manus is often turned inwards slightly and digits I-III sometimes curve forward on inwardly turned examples; this is especially the case in larger tracks. No curvature is found in digit IV. Digits and their corresponding area of the sole become increasingly deeply impressed from digit I to digit IV. There is no strongly impressed heel print. In some cases this is due to the manus print being overlapped by the digits of the pes, possibly obscuring any heel impression that may otherwise have formed. width $(42-105 \mathrm{~mm})$ is generally greater than length $(21-112 \mathrm{~mm})$ where such measurements are possible, apart from in the larger specimens in which length is typically greater than width. Digits are broad, longer than those of the manus and often lack any impression at the tips of digits III-V, especially in the case of larger tracks. Digit IV is the longest (13-61 mm) followed

171 by digit III (12-47 $\mathrm{mmm})$. Digits II and V are intermediate and similar in length (10-36 $\mathrm{mm}$ and 12-39 mm respectively) whilst digit I is the shortest (6-24 $\mathrm{mm})$. Digits III and IV may exhibit a 173 slight outward curvature, whereas the others are straight. Digits I and II have the strongest 
174 impressions, and the impressions decrease from digit III to digit V. The pes occasionally has a

175 slight outward angulation. A heel is more strongly impressed than is the case with the manus but

176 is still faint and often mostly absent.

Manus-pes overlap does occur but it is infrequent, slight, and difficult to judge due to the

178 poor impression of the heel of the manus. The placement of the pes is posterior to and tends to be

179 slightly lateral of the manus, with the exception of BIRUG BU5271 in which overstepping of the

180 manus by the pes appears to be present (see below). Due to the fact that the described footprints

181 are almost entirely isolated examples or from incomplete trackways, information on the

182 morphology of the trackways is scarce. Available trackway measurements for BIRUG BU5271

183 are as follows: manus-pes separation $36 \mathrm{~mm}$; manus stride $123 \mathrm{~mm}$; manus stride: footlength 4.6;

184 pes stride: $105 \mathrm{~mm}$; pes pace $65 \mathrm{~mm}$; pes trackwidth $50 \mathrm{~mm}$. A solitary large manus-pes pair

185 measured $114 \mathrm{~mm}$ for manus-pes separation.

186

187 Discussion: The classification of this material using open nomenclature at the ichnospecies level is a result of the limited material available and the generally isolated nature of the footprints. The tracks have previously been assigned to L. vagus, an ichnospecies that tends to be approximately a third of the size of the largest tracks found amongst the Hamstead material (Tucker \& Smith,

191 2004). Many previously erected ichnospecies within the Limnopus ichnogenus are now considered synonymous with L. vagus, but assigning the Hamstead specimens to L. vagus or any other ichnospecies is difficult without more complete trackways. Such large tracks of Limnopus

194 are not unheard of; indeed unpublished tracks have been measured at over $200 \mathrm{~mm}$ in length 195 (Voigt \& Haubold, 2015). 
197 198

199

200

201

202

203

204

205

206

207

208

209

210

211

212

213

214

215

216

consistent in morphology with the other examples of Limnopus, the tracks in BIRUG BU5271

are considerably smaller, and are the only examples known from Hamstead to show apparent overstepping of the manus by the pes.

Limnopus tracks are known from all over Europe, with examples known from Britain (Tucker \& Smith, 2004), Germany (Haubold, 1971, 1996; Voigt, 2005), Spain (Voigt \& Haubold, 2015), France (Gand \& Durand, 2006), Poland (Ptaszyński \& Niedźwiedzki, 2004; Niedźwiedzki, 2015), and Italy (Marchetti, Avanzini \& Conti, 2013; Marchetti et al., 2015). They are also known from the USA (Lucas et al., 2011; Lucas \& Dalman, 2013), Canada (Van Allen, Calder \& Hunt, 2005), Argentina (Hunt \& Lucas, 1998) and Morocco (Voigt et al., 2011a; Voigt et al., 2011b). They appear to range from the middle Moscovian to the middle Kungurian (Tucker \& Smith, 2004; Voigt \& Lucas, 2015). The trackmakers are considered to have been medium-large temnospondyl amphibians (Haubold, 1971; Gand, 1987; Haubold, 2000; Tucker \& Smith, 2004; Voigt, 2005; Gand \& Durand, 2006; Voigt \& Haubold, 2015).

Batrachichnus salamandroides Geinitz, 1861 (Fig. 3)

Referred material: BIRUG BU3294, set of multiple extremely tiny prints; BIRUG BU5280, approximately eight very poorly preserved prints representing a single trackway; BIRUG BU5285, relatively well preserved trackway of ten manus-pes pairs and a tail drag. 
217 Description: Tetradactyl and plantigrade manus of small size. Manus width (6-14 mm) is

218 generally greater than manus length $(7-13 \mathrm{~mm})$. Digits of the manus are generally straight with

219 an occasional inward curvature in digit III. Digit proportions are hard to determine and vary

220 throughout the trackway though it appears digit I is shortest in most cases $(1-4 \mathrm{~mm})$ and digit II

221 longest (3-5 mm). Digits III and IV both range from 2-4 $\mathrm{mm}$ in length. Manus is less strongly

222 impressed than the pes though the whole foot is often represented, showing a gently rounded

223 heel. This is obscured by an overlapping pes in two cases. Manus appears slightly more deeply

224 impressed towards the digits.

225 Pes is pentadactyl and also plantigrade. Pes width $(10-16 \mathrm{~mm})$ is generally greater than

226 pes length $(8-15 \mathrm{~mm})$. Digits are straight and show a slight distal taper in some cases. Though

227 digit I is clearly the shortest $(2-3 \mathrm{~mm})$ the rest of the proportions are unclear and vary. Digit III

228 is the longest on average $(4-6 \mathrm{~mm})$ followed by digit IV $(3-6 \mathrm{~mm})$. Digits II and V are similar in

229 length on average (3-4 $\mathrm{mm}$ and $2-5 \mathrm{~mm}$ respectively). The pes is more strongly impressed than

230 the manus showing a rounded heel. Pes appears more deeply impressed towards the inner digits.

231 Manus is sometimes rotated inward, although this varies greatly within the trackway. A

232 clear and continuous tail drag is present throughout. Manus stride 40-51 mm, manus pace 25-32

$233 \mathrm{~mm}$, pes stride 35-48 $\mathrm{mm}$, pes pace 29-35 mm, manus-pes separation 6-17 mm. Pes track width

$234(26 \mathrm{~mm})$ slightly exceeds that of the manus $(19 \mathrm{~mm})$.

235

236 Discussion: These small tracks with a tetradactyl manus and tail drag match the characteristics of

237 Batrachichnus salamandroides. It is considered the only valid ichnospecies within the genus

238 Batrachichnus (Tucker \& Smith, 2004; Voigt, 2005). Within the material assigned to $B$. 
239 salamandroides are a set of extremely small tracks (BIRUG BU3294) each no more than $4 \mathrm{~mm}$

240 in length. Their tiny size and poor preservation prevents accurate measurement but nevertheless

241 their size, track morphology, and the presence of a tail drag are consistent with $B$.

242 salamandroides and similar to the tracks reported by Stimson, Lucas \& Melanson (2012).

The larger B. salamandroides tracks amongst the Hamstead material are very similar in appearance to those assigned to Limnopus isp.. They do however have relatively longer digits on the manus, a characteristic of Batrachichnus (Haubold, 1996, Voigt, 2005). The similarity between Batrachichnus and Limnopus is unsurprising as there has been much debate on the taxonomic relationship between the two ichnogenera (Haubold, 1996, 2000; Tucker \& Smith, 2004; Voigt, 2005; Lucas et al., 2011; Voigt et al., 2011a; Voigt et al., 2011b), with

Batrachichnus possibly representing a juvenile form of Limnopus. It has been suggested that

Batrachichnus should be reassigned as a subgenus of Limnopus (Tucker \& Smith, 2004) but this

251 has generally been rejected by subsequent workers (Lucas et al., 2011). The relationship between

252 the two remains questionable and the incomplete nature of the Hamstead trackways does not help 253 the issue. assemblages, ranging from middle Moscovian to the Changhsingian (Tucker \& Smith, 2004; Voigt \& Lucas, 2015), with examples known from Britain (Tucker \& Smith, 2004), Spain (Voigt

257 \& Haubold, 2015), France (Gand \& Durand, 2006), Germany (Voigt, 2005), Poland (Ptaszyński

258 \& Niedźwiedzki, 2004; Niedźwiedzki, 2015), and Italy (Avanzini et al., 2008; Marchetti, 259 Avanzini \& Conti, 2013). It has also been found in the USA (Lucas et al., 2011; Voigt, Lucas \& 260 Krainer, 2013; Voigt \& Lucas, 2015), Canada (Stimson, Lucas \& Melanson, 2012), Argentina 261 (Melchor \& Sarjeant, 2004), and Morocco (Voigt et al., 2011a; Voigt et al., 2011b). 
262 Batrachichnus tracks are considered to have been made by small temnospondyl amphibians

263 (Haubold, 1971, 1996, 2000; Tucker \& Smith, 2004; Voigt, 2005).

264

265

Dimetropus leisnerianus Geinitz, 1863 (Fig. 4)

266

267

Referred material: BIRUG BU5269, three very poorly preserved tracks; BIRUG BU5275, three

268 very poorly preserved tracks; BIRUG BU5277, single pes; BIRUG BU5279, manus and pes pair.

Description: Semi-digitigrade and pentadactyl manus. Only one faintly impressed example missing most of digits IV and $\mathrm{V}$ exists amongst the material, approximately $47 \mathrm{~mm}$ in length and at least $59 \mathrm{~mm}$ in width. Digits are not impressed along their whole length; generally only rounded, hemispherical impressions at the front of the sole representative of the metatarsalphalangeal pads of the manus, and relatively deeply impressed claw marks are preserved. The impression of the claw for digit I is rotated laterally away from the others which face forward. Digit I is shorter than II and III which are very similar in length. The anteroposteriorly elongated

277 sole and heel typical of Dimetropus (Romer \& Price, 1940; Voigt \& Ganzelewski, 2010; Voigt et al., 2011a; Voigt et al., 2011b; Voigt \& Lucas, 2015) is not preserved amongst the material.

281 followed by digit V (21-23 mm), digit III (20 mm), and digit II (14-20 mm), with digit I being the shortest (10-21mm). The impressions are weak; digits are not well preserved and are 
283 generally represented by hemi-spherical impressions of the metatarsal-phalangeal pads and claw

284 marks, as in the manus. No elongated sole or heel is preserved in the pes.

Very little information can be identified or measured pertaining to trackways other than a 286 manus-pes separation of $79 \mathrm{~mm}$. There is no evidence of a tail drag.

Discussion: The tracks assigned to Dimetropus leisnerianus are generally quite poorly preserved, which is not uncommon (Voigt \& Lucas, 2015), yet the tracks still show rather well the hemispherical impressions of the metatarsal-phalangeal pads and deep claw marks characteristic of Dimetropus. BIRUG BU5269 and BIRUG BU5275 are extremely poorly preserved, being deeply but morphologically poorly defined likely as a result of the substrate. In the case of an isolated track, such as BIRUG BU5277, manus and pes can be discerned by the relative length of digit V (Voigt, 2005). In the manus, the length of digit V corresponds with that of digit II. In the pes, the length of digit V corresponds instead that of with digit III. The latter is the case in BIRUG BU5277; thus it is identified as a pes track. although a new ichnospecies, Dimetropus osageorum, has been recently proposed (Sacchi et al., 2014). Dimetropus osageorum tracks exhibit proportionally shorter digits and a greater degree of heteropody than D. leisnerianus. This is not seen in the tracks from Hamstead which match the characteristics of $D$. leisnerianus well and thus the material is assigned to that ichnospecies here. 
305 Niedźwiedzki, 2004; Niedźwiedzki \& Bojanowski, 2012; Voigt et al., 2012), North America

306 (Hunt et al., 2004; Sacchi et al., 2014; Voigt \& Lucas, 2015), Morocco (Voigt et al., 2011a;

307 Voigt et al., 2011b), and Argentina (Hunt \& Lucas, 1998). Dimetropus tracks have been found

308 from the middle Moscovian to the middle Kungurian (Tucker \& Smith, 2004; Voigt \& Lucas,

309 2015). The trackmakers are considered to have been non-therapsid synapsids ('pelycosaurs')

310 such as sphenacodonts, caseids, edaphosaurids, and ophiacodontids (Haubold, 2000; Voigt,

311 2005; Voigt \& Ganzeleweski, 2010; Romano, Citton \& Nicosia, 2015).

312

313

Dromopus lacertoides Geinitz, 1861 (Fig. 5)

314

315

Referred material: BIRUG BU5281, mostly indiscernible mass of tracks (Hardaker 1912: fig 26;

Haubold \& Sarjeant 1973: plate 6, fig. 1); BIRUG BU5282, single track (Fig. 5).

Description: The surface of BIRUG BU5281 is covered with a mass of tracks in which no clear trackways can be identified. The absence of a trackway prevents manus and pes from being distinguished, as they are morphologically almost identical in this ichnogenus (Voigt, 2005). These tracks are digitigrade and pentadactyl. All tracks are either incomplete or poorly

322 preserved, preventing accurate measurement of length and width. Digit IV appears the longest 323 (9-21 mm), followed by digit III $(5-14 \mathrm{~mm})$, digit II $(2-10 \mathrm{~mm})$, digit I (2-8mm), then digit V $324(3 \mathrm{~mm})$. Digits II-IV curve inwards and all digits are elongate and slender. 
326 digitigrade, length $(48 \mathrm{~mm})$ is greater than width (43 mm). Digit IV is the longest (43 $\mathrm{mm})$,

327 followed by digit III $(34 \mathrm{~mm})$, digit II $(30 \mathrm{~mm})$, digit I $(19 \mathrm{~mm})$, then digit V $(10 \mathrm{~mm})$. Digits II-

328 IV curve inwards, whilst digit $\mathrm{V}$ is clearly directed out from the manus laterally and curves

329 slightly towards the rear. All digits are long, slender, and end in a more deeply impressed 330 circular tip.

Discussion: There appear to be many tracks of this type amongst the Hamstead material, but few are measurable: the vast majority occur within specimen BIRUG BU5281 as a confused, poorly preserved, and densely packed and frequently overlapping assemblage. A differentiation of species within the ichnogenus Dromopus beyond that of the type species has not yet been convincingly produced (Gand, 1987; Haubold, 1996, 2000; Haubold \& Lucas, 2003; Voigt, 2005; Voigt \& Haubold, 2015; Voigt \& Lucas, 2015). As a result, these tracks among the Hamstead material are assigned to D. lacertoides, the only currently valid ichnospecies, with which they are morphologically consistent.

Dromopus is a very abundant ichnogenus, the most common and widespread tetrapod track of the late Palaeozoic (Haubold, 1971, 1996, 2000; Gand, 1987; Voigt, 2005, 2007, 2012; Lucas \& Hunt, 2006; Lucas, 2007), being known within Europe in Germany (Haubold, 1971; Voigt, 2005), France (Gand, 1987; Gand \& Durand, 2006), Spain (Voigt \& Haubold, 2015), Italy

344 (Avanzini et al., 2008), Russia (Lucas, Lozovsky \& Shishkin, 1999), and Poland (Voigt et al., 345 2012). It has also been reported from the USA (Lucas et al., 2011; Voigt, Lucas \& Krainer, 2013; 346 Voigt \& Lucas, 2015), Canada (Van Allen, Calder \& Hunt, 2005), and Morocco (Voigt et al., 347 2011a; Voigt et al., 2011b). Dromopus tracks elsewhere range from the late Moscovian to the 
348 Changhsingian (Tucker \& Smith, 2004; Voigt \& Lucas, 2015). The Enville Member which bears

349 the Hamstead assemblage has been dated as late Moscovian or Kasimovian on the basis of

350 macroflora. It is therefore possible that the Hamstead material is one of the stratigraphically

351 earliest occurrences of the Dromopus ichnogenus. Tracks of this type are thought to have been

352 produced by lizard-like sauropsids (eureptiles and parareptiles) of small-medium size such as

353 bolosaurids and araeoscelids (Haubold, 1971, 1996, 2000; Gand, 1987; Haubold \& Lucas, 2003;

354 Voigt, 2005; Gand \& Durand, 2006).

355

356 Tetrapoda indet.

357

358

Referred material: BIRUG BU5273, two manus-pes pairs and an isolated manus forming a trackway; BIRUG BU5274, indiscernible mass of prints; BIRUG BU5276, approximately six very poorly preserved prints; BIRUG BU5283, partial pes.

Discussion: a number of tracks within the Hamstead material are too poorly preserved to identify to ichnogenus. Those of BIRUG BU5273 resemble those assigned to both Limnopus and Batrachichnus salamandroides, but are intermediate in size between the two. As such we leave them unassigned at the generic level. The following trackway measurements are possible for BIRUG BU5273: manus-pes separation $38 \mathrm{~mm}$ and $46 \mathrm{~mm}$; manus stride $116 \mathrm{~mm}$; manus pace $76 \mathrm{~mm}$ and $69 \mathrm{~mm}$; manus stride: footlength 5.9; pes pace $92 \mathrm{~mm}$; manus trackwidth $40 \mathrm{~mm}$; pes 368 trackwidth $62 \mathrm{~mm}$. 


\section{Discussion}

371 The late Carboniferous was an interval of major environmental change on a global scale.

372 Increasing aridity during the late Moscovian and the Kasimovian led to the collapse and

373 fragmentation of the widespread, humid, tropical rainforests (the 'Coal Forests') that were so

374 typical of the Carboniferous period. This has been recognised as one of the two key mass

375 extinction events in the plant fossil record (Cascales-Miñana \& Cleal, 2013) and was likely the

376 driving force of significant changes in terrestrial tetrapod communities (Sahney et al., 2010).

377 Amphibians, which dominated ecosystems during the Carboniferous, declined in diversity,

378 whereas early amniotes appear to have been largely unaffected and continued to diversify

379 (Sahney et al., 2010). The success of amniotes has been linked to their greater independence

380 from water, potentially providing the group with an ecological advantage in the new, drier

381 conditions. The footprint assemblages of the Salop Formation from Alveley (Alveley Member)

382 and Hamstead (Enville Member) potentially capture key phases of this faunal transition, dating

383 as they do to the late Moscovian (Westphalian D) and late Moscovian-Kasimovian (Westphalian

384 D-Stephanian), respectively.

The Hamstead assemblage has yielded four classic late Carboniferous-Early Permian ichnotaxa: Limnopus isp., Batrachichnus salamandroides, Dimetropus leisnerianus, and

Dromopus lacertoides, representing temnospondyl amphibians of a range of different sizes, early synapsids (pelycosaurs), and sauropsid reptiles. The stratigraphically older tracks from Alveley include six ichnospecies: Ichniotherium willsi, Hyloidichnus bifurcatus (albeit identified with some uncertainty on the basis of a single, poorly preserved specimen), Dimetropus leisnerianus, 
392 2004), representing the taxa present at Hamstead, as well as diadectomorphs (Ichniotherium) and

393 possibly also captorhinomorphs (single track of ?Hyloidichnus) (Haubold, 2000; Tucker \&

394 Smith, 2004; Voigt et al. 2007, 2010). Hyloidichnus bifurcatus and Ichniotherium willsi are each

395 rare in the Alveley material so their absence at Hamstead could feasibly be explained by the

396 much smaller sample size known from the latter locality. It is also possible that over the time

397 between the deposition of the Alveley Member and the Enville Member the trackmakers of

398 Ichniotherium willsi and Hyloidichnus bifurcatus became locally (although not globally) extinct

399 due to environmental changes. Differing environmental conditions could also be an explanation

400 for the much greater size range of Limnopus tracks seen within the Hamstead assemblage when

401 compared to Alveley. Table 2 contrasts tetrapod ichnotaxa reported from Alveley (Tucker \&

402 Smith, 2004) and Hamstead alongside their supposed trackmakers.

One key difference between the assemblages from Alveley and Hamstead is the presence

404

405

406

407

408

409

410

411

412

413

414 of Dromopus lacertoides at Hamstead, and its absence within the Alveley assemblage. The described ichnotaxa from Alveley are characteristic of marginal freshwater-terrestrial tetrapod communities (Tucker \& Smith, 2004) whereas Dromopus, though also found in wet

environments, is commonly associated with dune facies and more arid or inland environments, such as those with shallow lacustrine or playa-like settings (Tucker and Smith, 2004; Marchetti \& Avanzini, 2011). Tetrapod ichnofaunal change through the late Carboniferous-early Permian has been observed in the USA, with assemblages becoming increasingly dominated by Dromopus tracks, whilst the tracks of temnospondyls (Limnopus and Batrachichnus) decline (Lucas, Krainer \& Voigt, 2013). The Alveley and Hamstead assemblages likely document a similar ichnofaunal and environmental change. 


\section{Acknowledgements}

416 The authors would like to thank Kate Riddington and Jon Clatworthy (Lapworth Museum of

417 Geology) for their help and for access to the specimens, and Sebastian Voigt for discussion. We

418 thank Sebastian Voigt and Grzegorz Niedźwiedzki for review comments that improved the final 419 manuscript, and Jérémy Anquetin for editorial suggestions.

\section{References}

423 Andrews CEA. 1973. Walter Henry Hardaker (1877-1970). Watsonia 9:177.

424 Avanzini M, Neri C, Nicosia U, Conti MA. 2008. A new Early Permian ichnocoenosis from the “Gruppo vulcanico atesino”(Mt. Luco, Southern Alps, Italy). Studi Trentini di Scienze Naturali - Acta Geologica 83:231-236.

427

428

429

430

431

432

433

Besly BM. 1988. Palaeogeographic implications of late Westphalian to early Permian red-beds, central England. In: Besley BM, Kelling J, eds. Sedimentation in a Synorogenic Basin Complex: the Upper Carboniferous of Northwest Europe. Glasgow: Blackie, 200-221.

Besly BM, Cleal CJ. 1997. Upper Carboniferous stratigraphy of the West Midlands (UK) revised in the light of borehole geophysical logs and detrital compositional suites. Geological Journal 32:85-118. DOI: 10.1002/(SICI)1099-1034(199706)32:2<85::AIDGJ732>3.0.CO;2-O 
434 Cascales-Miñana B, Cleal CJ. 2013. The plant fossil record reflects just two great extinction 435 events. Terra Nova 26:195-200. DOI: 10.1111/ter.12086

436

437

438

439

440

441

442

443

444

445

446

447

448

449

450

451

452

Gand G. 1987. Les traces de vertébrés tétrapodes du Permien français: Paléontologie, stratigraphie, paléoenvironnements. $\mathrm{PhD}$ thesis, Université de Bourgogne.

Gand G, Durand M. 2006. Tetrapod footprint ichno-associations from French Permian basins. Comparisons with other Euramerican ichnofaunas. Geological Society, London, Special Publications 265:157-177.

Geinitz HB. 1861. Dyas oder die Zechsteinformation und das Rothliegende (permische Formation zum Theil). Leipzig: W. Engelmann.

Geinitz HB. 1863. Beiträge zur Kenntnis der organischen Überreste in der Dyas (oder permischen Formation zum Theil) und über den Namen Dyas. Neues Jahrbuch für Mineralogie, Geologie und Paläontologie 1863:385-398.

Glover BW, Powell JH. 1996. Interaction of climate and tectonics upon alluvial architecture: Late Carboniferous-Early Permian sequences at the southern margin of the Pennine Basin, UK. Palaeogeography, Palaeoclimatology, Palaeoecology 121:13-34.

Gradstein FM, Ogg G, Schmitz M. 2012. The Geologic Time Scale 2012. Elsevier.

Hardaker WH. 1912. On the discovery of a fossil-bearing horizon in the "Permian" rocks of Hamstead Quarries, near Birmingham. Quarterly Journal of the Geological Society 68:639-683. DOI: 10.1144/gsl.jgs.1912.068.01-04.36. 
453 Haubold H. 1971. Ichnia amphibiorum et reptiliorum fossilium. Encyclopedia of

454 Palaeoherpetology Part 18. Stuttgart: Gustav Fischer Verlag. 1-128.

455 Haubold H. 1996. Ichnotaxonomie und Klassifikation von Tetrapodenfährten aus dem Perm.

$456 \quad$ Hallesches Jahrbuch für Geowissenschaften. 18:23-88.

457 Haubold H. 2000. Tetrapodenfährten aus dem Perm - Kenntnisstand und progress 2000.

$458 \quad$ Hallesches Jahrbuch für Geowissenschaften. 22:1-16.

459 Haubold H, Lucas SG. 2003. Tetrapod footprints of the Lower Permian Choza Formation.

460 Paläontologische Zeitschreift 77:247-261. DOI: 10.1007/BF03006940

461 Haubold H, Sarjeant WAS. 1973. Tetrapodenfährten aus dem Keele und Enville Groups

462 (Permokarbon; Stefan und Autun) von Shropshire und South Staffordshire,

463 Großbrittannien. Zeitschrift der geologische Wissenschaften, Berlin 1:895-933.

464 Haubold H, Sarjeant WAS. 1974. Fossil vertebrate footprints and the stratigraphical correlation

465 of the Keele and Enville Beds of the Birmingham region. Proceedings of the Birmingham

$466 \quad$ Natural History Society 22:257-268.

467 Hunt AP, Lucas SG. 1998. Implications of the cosmopolitanism of Permian tetrapod

468 ichnofaunas. New Mexico Museum of Natural History and Science Bulletin 12:55-58.

469 Hunt AP, Lucas SG, Lockley MG. 2004. Large pelycosaur footprints from the Lower

470 Pennsylvanian of Alabama, USA. Ichnos 11:39-44. DOI: 10.1080/10420940490428715 
471 Johnson SA, Glover BW, Turner P. 1997. Multiphase reddening and weathering events in Upper

472 Carboniferous red beds from the English West Midlands. Journal of the Geological Society

473 154:735-745. DOI: 10.1144/gsjgs.154.4.0735

474 Lucas SG. 2007. Tetrapod footprint biostratigraphy and biochronology. Ichnos 14:5-38. DOI:

475 $10.1080 / 10420940601006792$

476

477

478

479

480

481

482

483

484

485

486

487

488

489

490

Lucas SG, Dalman S. 2013. Alfred King's Pennsylvanian tetrapod footprints from western Pennsylvania. New Mexico Museum of Natural History and Science Bulletin 60:233-239.

Lucas SG, Hunt AP. 2006. Permian tetrapod footprints: biostratigraphy and biochronology. Geological Society, London, Special Publications 265:179-200. DOI:

10.1144/GSL.SP.2006.265.01.08

Lucas SG, Krainer K, Voigt S. 2013. The Lower Permian Yeso Group in central New Mexico. New Mexico Museum of Natural History and Science Bulletin 59:181-200.

Lucas SG, Lozovsky VR, Shishkin MA. 1999. Tetrapod footprints from early Permian redbeds of the northern Caucasus, Russia. Ichnos 6:277-281. DOI: 10.1080/10420949909386459.

Lucas SG, Voigt S, Lerner AJ, Nelson WJ. 2011. Late early Permian continental ichnofauna from Lake Kemp, north-central Texas, USA. Palaeogeography, Palaeoclimatology, Palaeoecology 308:395-404. DOI: 10.1016/j.palaeo.2011.05.047.

Marchetti L, Avanzini M. 2014. Revision of early Permian tetrapod ichnofauna, new insights from Lombardy and Trentino Alto-Adige (N Italy). Giornate di Paleontologia XIII edizione - Perugia. DOI: http//dx..org/10.13140/2.1.4416.7366. 
491 Marchetti L, Avanzini M, Conti MA. 2013. Hyloidichnus bifurcatus Gilmore, 1927 and

492 Limnopus heterodactylus (King, 1845) from the Early Permian of Southern Alps (N Italy):

493

494 a new equilibrium in the ichnofauna. Ichnos 20:202-217. DOI:

$10.1080 / 10420940.2013 .846261$

495

496

497

498

499

500

501

502

503

504

505

506

507

508

509

Marchetti L, Ronchi A, Santi G, Schirolli P, Conti MA. 2015. Revision of a classic site for Permian tetrapod ichnology (Collio Formation, Trompia and Caffaro valleys, N. Italy), new evidences for the radiation of captorhinomorph footprints. Palaeogeography, Palaeoclimatology, Palaeoecology 433:140-155. DOI: 10.1016/j.palaeo.2015.04.005

Marsh OC. 1894. Footprints of vertebrates in the coal measures of Kansas. American Journal of Science-Series 3 48:81-84. DOI: 10.2475/ajs.s3-48.283.81

Melchor RN, Sarjeant WAS. 2004. Small amphibian and reptile footprints from the Permian Carapacha Basin, Argentina. Ichnos 11:57-78. DOI: 10.1080/10420940490428814

Milner AC. 1994. A Carboniferous reptile footprint from the Somerset Coalfield. Proceedings of the Geologists' Association 105:313-315.

Niedzwiedzki G. 2015. Carboniferous tetrapod footprints from the Lublin Basin, SE Poland. GFF 137:57-65. DOI: 10.1080/11035897.2014.945618

Niedźwiedzki G, Bojanowski M. 2012. A supposed eupelycosaur body impression from the Early Permian of the Intra-Sudetic Basin, Poland. Ichnos 19:150-155. DOI: 10.1080/10420940.2012.702549. 
510 Pabst W. 1908. Die Tierfährten in dem Rotliegenden Deutschlands. Nova Acta Leopoldina

511 $89: 315-480$.

512 Powell JH, Chisholm JI, Bridge DM, Rees JG, Glover BW. 2000. Stratigraphical framework for

513 Westphalian to Early Permian red-bed successions of the Pennine Basin. British

514 Geological Survey Research Report RR/00/01. Available at: http://nora.nerc.ac.uk/3242/

$515 \quad$ (accessed 10 June 2016)

516 Ptaszyński T, Niedźwiedzki G. 2004. Late Permian vertebrate tracks from the Tumlin Sandstone, Holy Cross Mountains, Poland. Acta Palaeontologica Polonica 49:289-320.

518

519

520

521

522

523

524

525

526

527

528

529

Romano M, Citton P, Nicosia U. 2015. Corroborating trackmaker identification through footprint functional analysis: The case study of Ichniotherium and Dimetropus. Lethaia 49:102-116. DOI: $10.1111 /$ let.12136.

Romer AS, Price LW. 1940. Review of the Pelycosauria. Geological Society of America Special Papers 28:1-534. DOI: 10.1130/SPE28-p1

Romilio A, Salisbury SW. 2014. Large dinosaurian tracks from the upper Cretaceous (Cenomanian-Turonian) portion of the Winton formation, lark quarry, central-western Queensland, Australia: 3D photogrammetric analysis renders the "stampede trigger" scenario unlikely. Cretaceous Research 51:186-207. DOI: 10.1016/j.cretres.2014.06.003.

Sacchi E, Cifelli R, Citton P, Nicosia U, Romano M. 2014. Dimetropus osageorum n. isp. from the early Permian of Oklahoma (USA): A trace and its trackmaker. Ichnos 21:175-192. DOI: $10.1080 / 10420940.2014 .933070$. 
530 Sahney S, Benton MJ, Falcon-Lang HJ. 2010. Rainforest collapse triggered Carboniferous 531 tetrapod diversification in Euramerica. Geology 38: 1079-1082. DOI: 10.1130/g31182.1.

532 Stimson M, Lucas SG, Melanson G. 2012. The smallest known tetrapod footprints:

533 Batrachichnus salamandroides from the Carboniferous of Joggins, Nova Scotia, Canada. Ichnos 19: 127-140. DOI: 10.1080/10420940.2012.685206

Tucker L. 2003. Terrestrial tetrapod communities of the Late Palaeozoic: an ichnological 536 perspective. PhD thesis, University of Birmingham.

537 Tucker L, Smith MP. 2004. A multivariate taxonomic analysis of the late Carboniferous

$538 \quad$ vertebrate ichnofauna of Alveley, southern Shropshire, England. Palaeontology 47: 679539 710. DOI: $10.1111 / \mathrm{j} .0031-0239.2004 .00377 . x$.

540

541

542

543

544

545

546

547

548

549

Van Allen HEK, Calder JH, Hunt AP. 2005. The trackway record of a tetrapod community in a walchian conifer forest from the Permo-Carboniferous of Nova Scotia. New Mexico Museum of Natural History and Science Bulletin 30: 322-332.

Voigt S. 2005. Die Tetrapodenichnofauna des kontinentalen Oberkarbon und Perm im Thüringer Wald - Ichnotaxonomie. Paläoökologie und Biostratigraphie. Göttingen: Cuvillier Verlag.

Voigt S. 2007. Auf den Spuren der Saurier: Die Tetrapodenfährten aus dem Oberkarbon und Unterperm des Saar-Nahe-Beckens. In: Schindler T, Heidtke UHC, eds. Kohlesümpfe. Seen und Halbwüsten - Dokumente einer rund 300 Millionen Jahre alten Lebewelt zwischen Saarbrücken und Mainz. Hamburg: Pollichia Sonderveröffentlichung. 288-303. 
550 Voigt S. 2012. Fossilführung und Stratigraphie: Tetrapodenfährten im Rotliegend. In: Lützner H,

551 Kowalczyk G, eds. Stratigraphie von Deutschland X. - Rotliegend der variscischen

552 Innenbecken. Stuttgart: Schweizerbart. 161-175.

553 Voigt S, Ganzelewski M. 2010. Toward the origin of amniotes: diadectomorph and synapsid 554 footprints from the early late Carboniferous of Germany. Acta Palaeontologica Polonica $555 \quad$ 55:57-72. DOI: 10.4202/app.2009.0021.

556 Voigt S, Haubold H. 2015. Permian tetrapod footprints from the Spanish Pyrenees,

557 Palaeogeography, Palaeoclimatology, Palaeoecology 417:112-120. DOI:

$558 \quad$ 10.1016/j.palaeo.2014.10.038

559 Voigt S, Lucas SG. 2015. Permian tetrapod ichnodiversity of the Prehistoric Trackways National 560 Monument (south-central New Mexico, USA). Bulletin of the New Mexico Museum of $561 \quad$ Natural History and Science 65:153-168.

562 Voigt S, Berman DS, Henrici AC. 2007. First well-established track-trackmaker association of

563 Paleozoic tetrapods based on Ichniotherium trackways and diadectid skeletons from the 564 Lower Permian of Germany. Journal of Vertebrate Paleontology 27:553-570. DOI: 10.1671/0272-4634(2007)27[553:FWTAOP]2.0.CO;2

566 Voigt S, Lucas SG, Krainer K. 2013. Coastal-plain origin of trace-fossil bearing red beds in the 567 Early Permian of Southern New Mexico, USA. Palaeogeography, Palaeoclimatology, 568 Palaeoecology 369:323-334. DOI: 10.1016/j.palaeo.2012.10.041

569 Voigt S, Hminna A, Saber H, Schneider JW, Klein H. 2010. Tetrapod footprints from the 570 uppermost level of the Permian Ikakern Formation (Argana Basin, Western High Atlas, 
571

572

573

574

575

576

577

578

579

580

581

582

583

584

585

586

587

588

589

Morocco). Journal of African Earth Sciences 57:470-478. DOI:

10.1016/j.jafrearsci.2009.12.003

Voigt S, Lagnaoui A, Hminna A, Saber H, Schneider JW. 2011a. Revisional notes on the Permian tetrapod ichnofauna from the Tiddas Basin, central Morocco. Palaeogeography, Palaeoclimatology, Palaeoecology 302:474-483. DOI: 10.1016/j.palaeo.2011.02.010

Voigt S, Saber H, Schneider JW, Hmich D, Hminna A. 2011b. Late Carboniferous-Early Permian tetrapod ichnofauna from the Khenifra Basin, Central Morocco. Geobios 44:399407. DOI: 10.1016/j.geobios.2010.11.008

Voigt S, Niedźwiedzki G, Raczyński P, Mastalerz K, Ptaszyński T. 2012. Early Permian tetrapod ichnofauna from the Intra-Sudetic basin, SW Poland. Palaeogeography, Palaeoclimatology, Palaeoecology 313-314:173-180. DOI: 10.1016/j.palaeo.2011.10.018

Waters CN, Glover BW, Powell JH. 1994. Structural synthesis of S Staffordshire, UK: Implications for the Variscan evolution of the Pennine Basin. Journal of the Geological Society, London 151:697-713. DOI: 10.1144/gsjgs.151.4.0697. 


\section{Figure captions}

Fig. 1. Geographic setting of Hamstead and the site of discovery of the fossil assemblage, 'New Quarry'.

A. Location of Birmingham within Britain. B. Location of Hamstead Village approximately 3 miles NW of Birmingham city centre. C. Location of 'New Quarry' within the area of Hamstead.

Fig. 2. Specimens BIRUG BU5267 (A-C) and BIRUG BU5284 (D-E), well defined examples of Limnopus isp. tracks from Hamstead. All scale bars $10 \mathrm{~cm}$. A. Top-down photograph. B. Tracks rendered to show relief with an arbitrary scale. C. Tracks rendered to highlight areas of steep gradient, digitally isolating the outline of the tracks. D. Digital rendering (photogrammetric model). E. Tracks rendered to 603 show relief with an arbitrary scale.

604

Fig. 3. Batrachichnus salamandroides tracks from Hamstead. Tracks were too weakly impressed to create a useful photogrammetric model. A. Top-down photograph of specimen BIRUG BU5285, the most complete trackway of $B$. salamandroides amongst the material. Scale bar $10 \mathrm{~cm}$. B. Tiny $B$. salamandroides trackway from specimen BIRUG BU3294 accompanied by outline drawing. Scale bar $6091 \mathrm{~cm}$. 
611 Fig. 4. Specimens BIRUG BU5277 (left surface of slab) and BIRUG BU5278 (right surface of slab), a

612 Dimetropus leisnerianus pes print and Limnopus isp. manus-pes pair respectively from Hamstead. A.

613 Top-down photograph. B. Tracks rendered to show relief with an arbitrary scale. C. Tracks are rendered

614 to highlight areas of steep gradient, digitally isolating the outline of the tracks. All scale bars $10 \mathrm{~cm}$.

615

616 Fig. 5. Specimen BIRUG BU5283, only well-defined example of a Dromopus lacertoides track from

617 Hamstead. All scale bars $2 \mathrm{~cm}$. A. Top-down photograph. B. Track rendered to show relief with an

618 arbitrary scale. C. Track rendered to highlight areas of steep gradient, digitally isolating the outline of the 619 track.

620

621

622

623

624

625

626

627

628

629

630

631 
Figure 1

Geographic setting of Hamstead and the site of discovery of the fossil assemblage, 'New Quarry'.

Fig. 1. Geographic setting of Hamstead and the site of discovery of the fossil assemblage, 'New Quarry'. A. Location of Birmingham within Britain. B. Location of Hamstead Village approximately 3 miles NW of Birmingham city centre. C. Location of 'New Quarry' within the area of Hamstead.
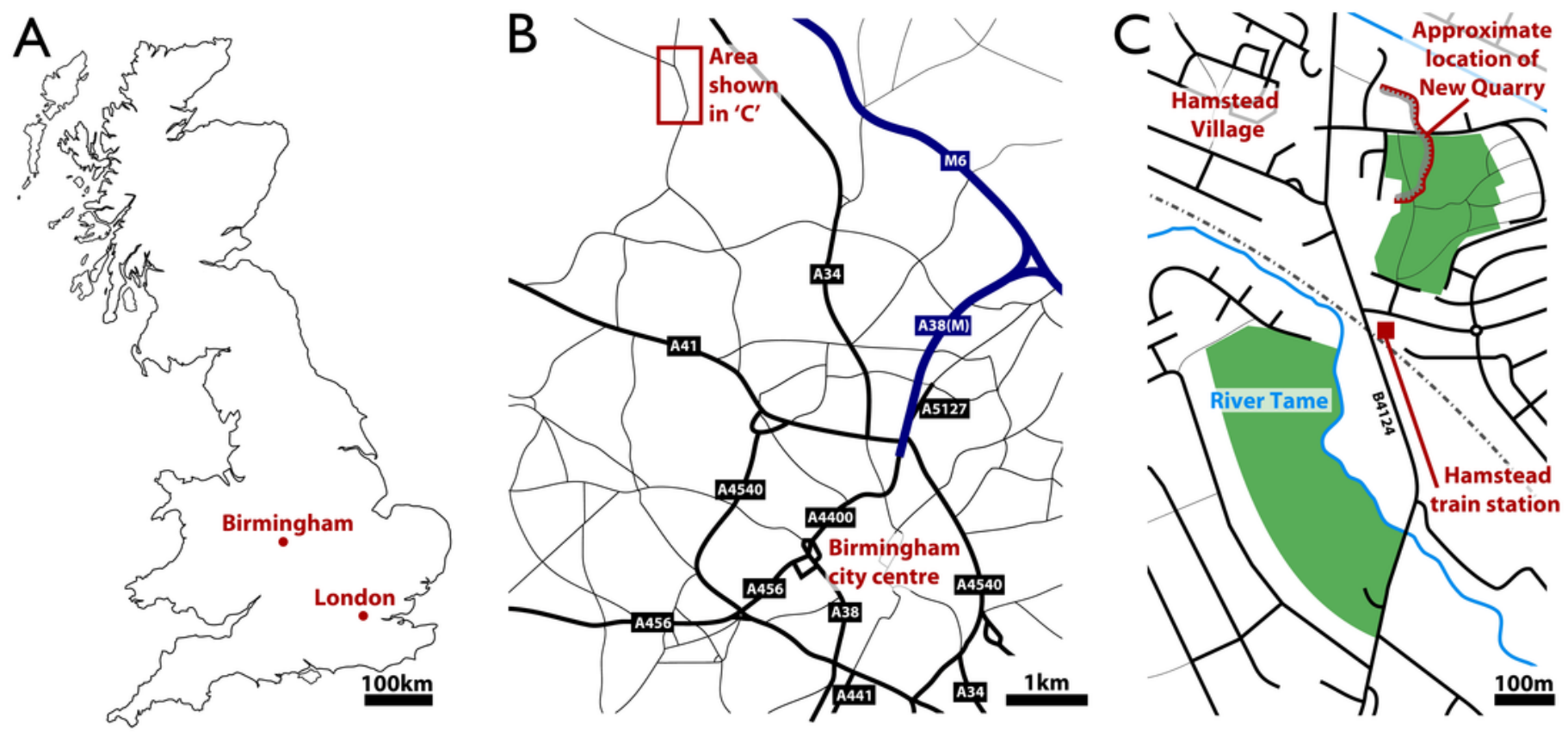


\section{Figure 2}

Specimens BIRUG BU5267 (A-C) and BIRUG BU5284 (D-E), well defined examples of Limnopus isp. tracks from Hamstead.

Fig. 2. Specimens BIRUG BU5267 (A-C) and BIRUG BU5284 (D-E), well defined examples of Limnopus isp. tracks from Hamstead. All scale bars $10 \mathrm{~cm}$. A. Top-down photograph. B. Tracks rendered to show relief with an arbitrary scale. C. Tracks rendered to highlight areas of steep gradient, digitally isolating the outline of the tracks. D. Digital rendering (photogrammetric model). E. Tracks rendered to show relief with an arbitrary scale. 

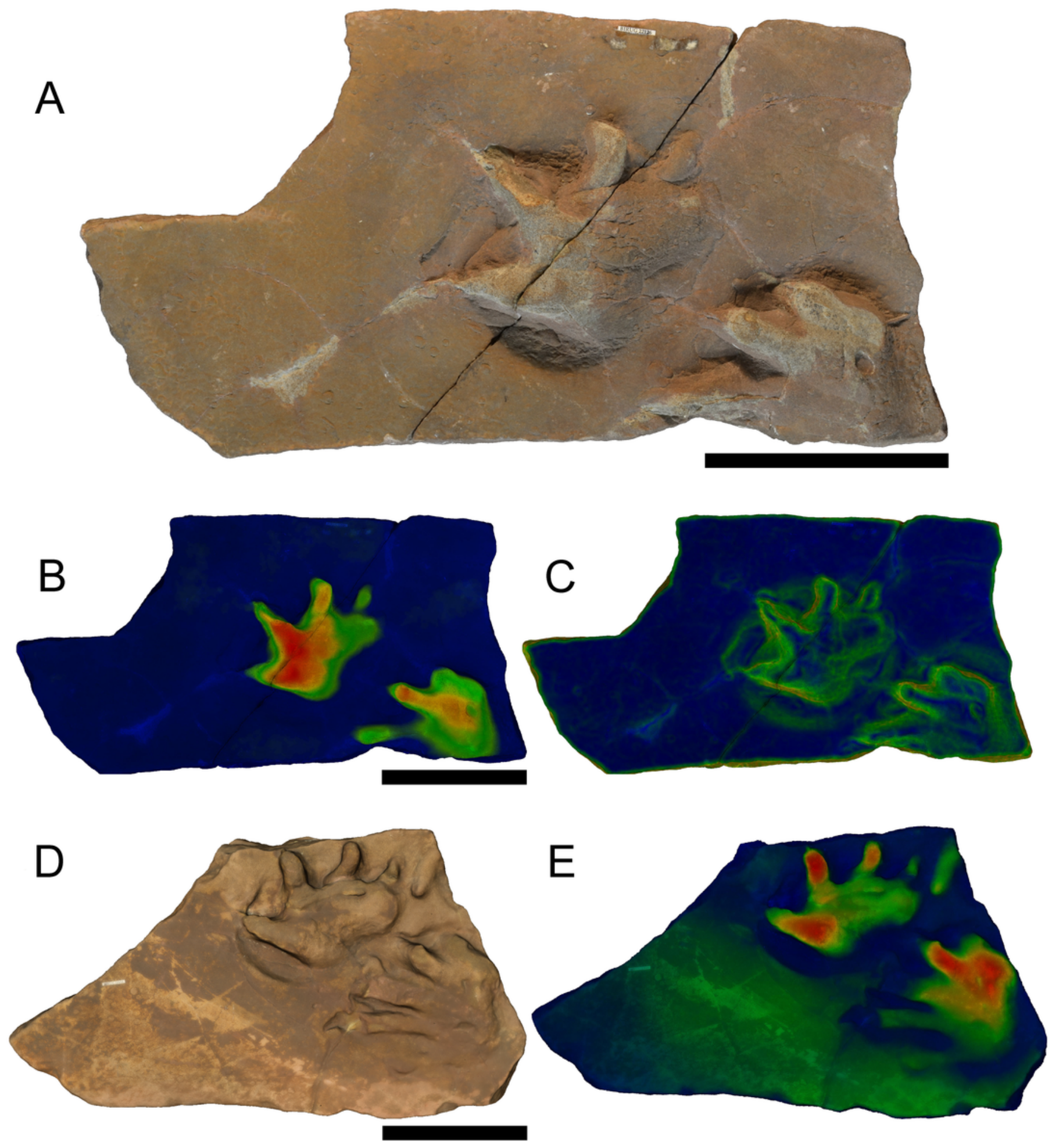


\section{Figure 3}

Batrachichnus salamandroides tracks from Hamstead.

Fig. 3. Batrachichnus salamandroides tracks from Hamstead. Tracks were too weakly impressed to create a useful photogrammetric model. A. Top-down photograph of specimen BIRUG BU5285, the most complete trackway of $B$. salamandroides amongst the material.

Scale bar $10 \mathrm{~cm}$. B. Tiny B. salamandroides trackway from specimen BIRUG BU3294 accompanied by outline drawing. Scale bar $1 \mathrm{~cm}$.
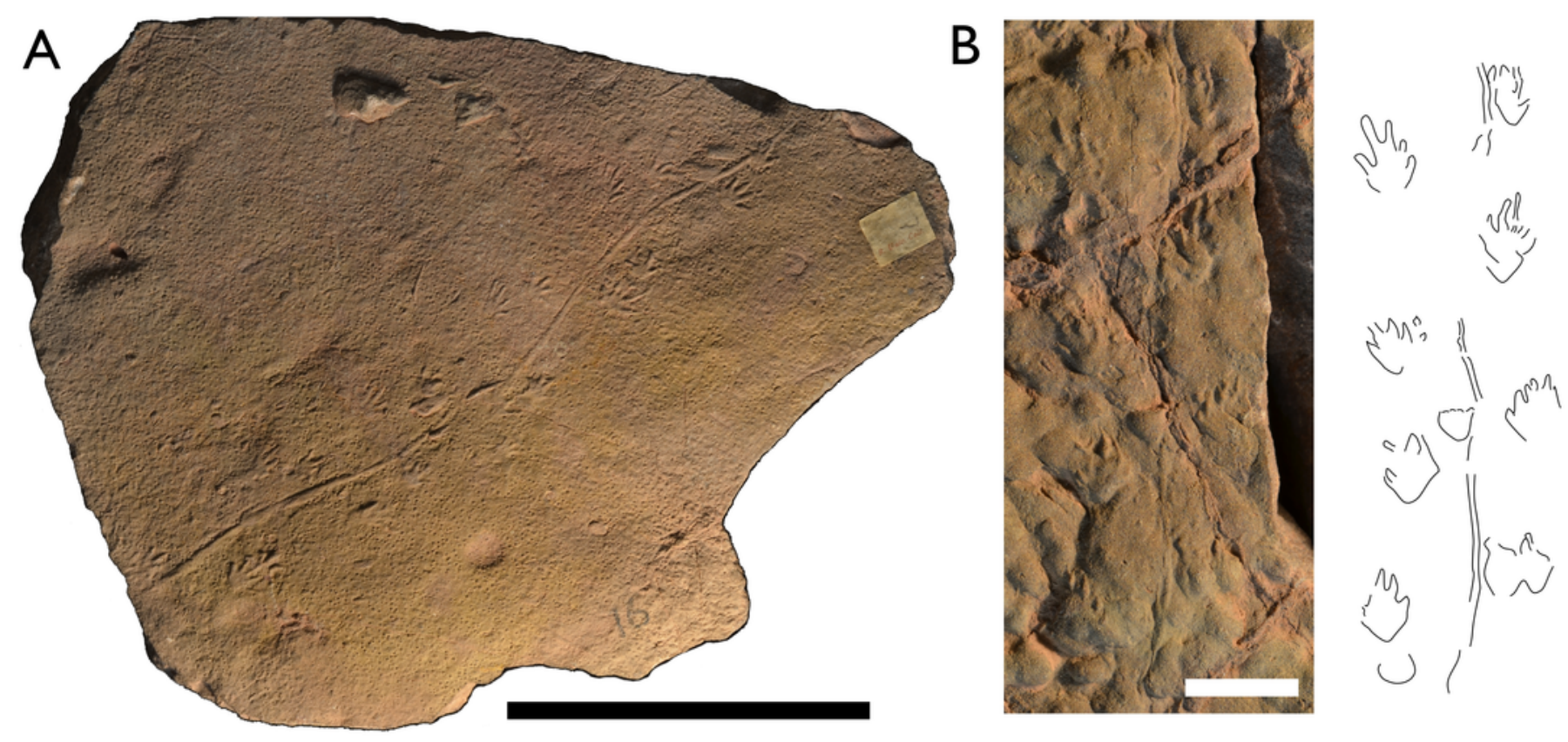


\section{Figure 4}

Specimens BIRUG BU5277 (left surface of slab) and BIRUG BU5278 (right surface of slab), a Dimetropus leisnerianus pes print and Limnopus isp. manus-pes pair respectively from Hamstead.

Fig. 4. Specimens BIRUG BU5277 (left surface of slab) and BIRUG BU5278 (right surface of slab), a Dimetropus leisnerianus pes print and Limnopus isp. manus-pes pair respectively from Hamstead. A. Top-down photograph. B. Tracks rendered to show relief with an arbitrary scale. C. Tracks are rendered to highlight areas of steep gradient, digitally isolating the outline of the tracks. All scale bars $10 \mathrm{~cm}$.
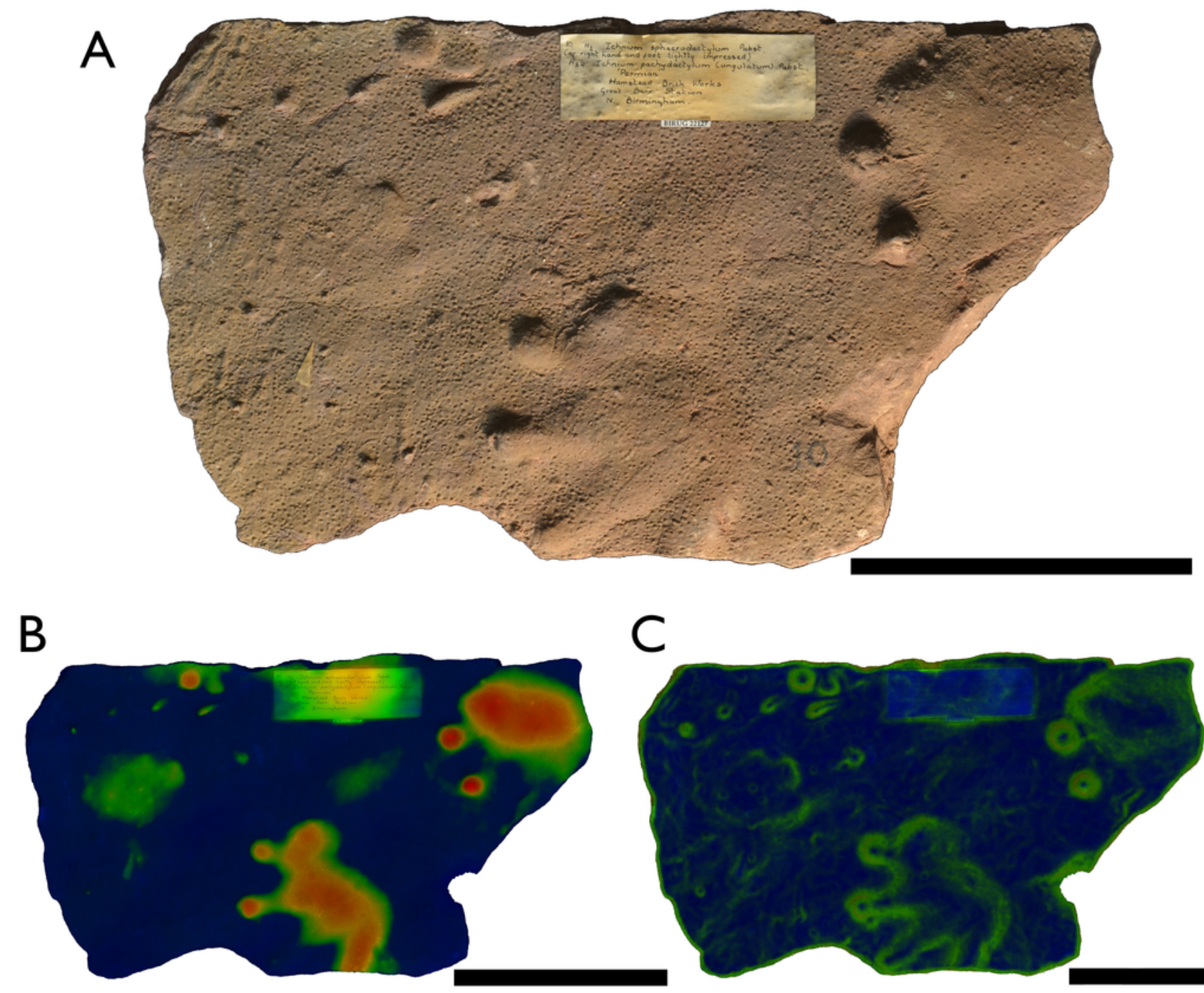

C 


\section{Figure 5}

Specimen BIRUG BU5283, only well-defined example of a Dromopus lacertoides pes from Hamstead.

Fig. 5. Specimen BIRUG BU5283, only well-defined example of a Dromopus lacertoides pes from Hamstead. All scale bars $2 \mathrm{~cm}$. A. Top-down photograph. B. Track rendered to show relief with an arbitrary scale. C. Track rendered to highlight area of steep gradient, digitally isolating the outline of the track.
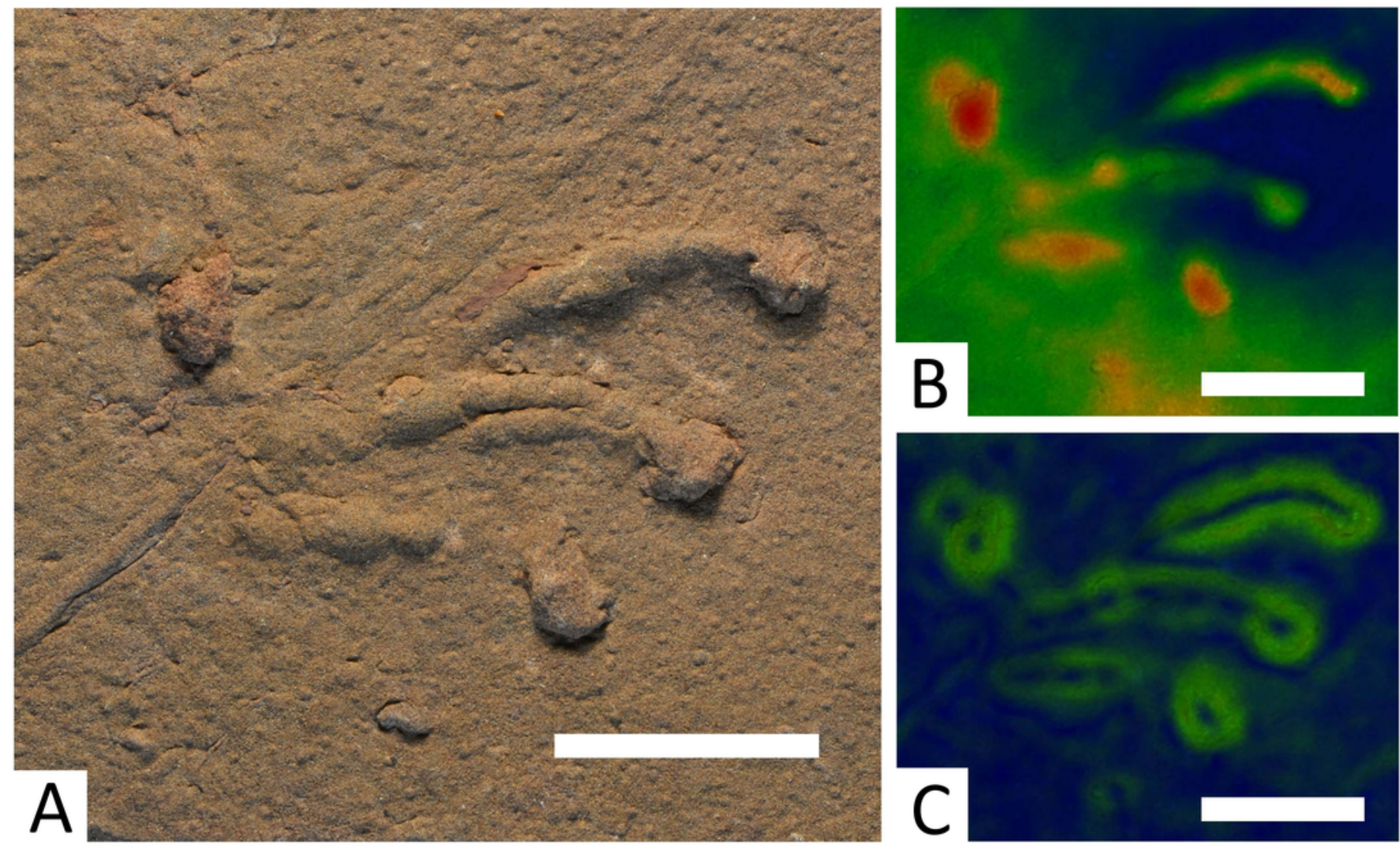


\section{Table $\mathbf{1}$ (on next page)}

Former identifications of the Hamstead material alongside the revised taxonomy from this study and the associated track makers. 
1 Table 1. Former identifications of the Hamstead material alongside the revised taxonomy from this study

2 and the associated track makers.

3

$\begin{array}{llllll}\text { Hardaker's } & \text { Hardaker 1912 } & \text { Haubold \& Sarjeant } & \text { Tucker 2003 } & \text { Revised taxonomy } & \text { Trackmaker } \\ \text { track } & \text { taxonomy } & 1973 \text { taxonomy } & \text { taxonomy } & \text { - this study } \\ \text { type numbers } & & & & \end{array}$

\begin{tabular}{|c|c|c|c|c|c|}
\hline H 1 & $\begin{array}{l}\text { Ichnium } \\
\text { sphaerodactylum }\end{array}$ & Ichniotherium cottae & Limnopus vagus & Limnopus isp. & $\begin{array}{l}\text { Temnospondyl } \\
\text { amphibian }\end{array}$ \\
\hline H 1a & Ichniotherium cottae & Ichniotherium cottae & Limnopus vagus & Limnopus isp. & $\begin{array}{l}\text { Temnospondyl } \\
\text { amphibian }\end{array}$ \\
\hline $\mathrm{H} 1 \mathrm{~b}$ & $\begin{array}{l}\text { Ichnium } \\
\text { sphaerodactylum minus }\end{array}$ & Not restudied & Limnopus vagus & Limnopus isp. & $\begin{array}{l}\text { Temnospondyl } \\
\text { amphibian }\end{array}$ \\
\hline H 2 & Ichnium pachydactylum & Not restudied & Limnopus vagus & Limnopus isp. & $\begin{array}{l}\text { Temnospondyl } \\
\text { amphibian }\end{array}$ \\
\hline $\mathrm{H} 2 \mathrm{a}$ & $\begin{array}{l}\text { Ichnium pachydactylum } \\
\text { minus }\end{array}$ & Not restudied & Limnopus vagus & Limnopus isp. & $\begin{array}{l}\text { Temnospondyl } \\
\text { amphibian }\end{array}$ \\
\hline $\mathrm{H} 2 \mathrm{~b}$ & $\begin{array}{l}\text { Ichnium pachydactylum } \\
\text { ungulatum }\end{array}$ & $\begin{array}{l}\text { Dimetropus } \\
\text { leisnerianus }\end{array}$ & $\begin{array}{l}\text { Dimetropus } \\
\text { leisnerianus }\end{array}$ & $\begin{array}{l}\text { Dimetropus } \\
\text { leisnerianus }\end{array}$ & $\begin{array}{l}\text { Non-theraspid } \\
\text { synapsid }\end{array}$ \\
\hline H 3 & Ichnium brachydactylum & $\begin{array}{l}\text { Gilmoreichnus } \\
\text { brachydactylum }\end{array}$ & $\begin{array}{l}\text { Hyloidichnus } \\
\text { bifurcatus }\end{array}$ & $\begin{array}{l}\text { Batrachichnus } \\
\text { salamandroides }\end{array}$ & $\begin{array}{l}\text { Temnospondyl } \\
\text { amphibian }\end{array}$ \\
\hline H 4 & Ichnium doliodactylum & $\begin{array}{l}\text { Anthichnium } \\
\text { salamandroides }\end{array}$ & $\begin{array}{l}\text { Limnopus } \\
\text { salamandroides }\end{array}$ & $\begin{array}{l}\text { Batrachichnus } \\
\text { salamandroides }\end{array}$ & $\begin{array}{l}\text { Temnospondyl } \\
\text { amphibian }\end{array}$ \\
\hline H 5 & $\begin{array}{l}\text { Ichnium } \\
\text { gampsodactylum }\end{array}$ & $\begin{array}{l}\text { Dromopus } \\
\text { lacertoides }\end{array}$ & $\begin{array}{l}\text { Dromopus } \\
\text { lacertoides }\end{array}$ & $\begin{array}{l}\text { Dromopus } \\
\text { lacertoides }\end{array}$ & Sauropsida \\
\hline H 5a & $\begin{array}{l}\text { Ichnium } \\
\text { gampsodactylum minus }\end{array}$ & $\begin{array}{l}\text { Dromopus } \\
\text { lacertoides }\end{array}$ & $\begin{array}{l}\text { Dromopus } \\
\text { lacertoides }\end{array}$ & $\begin{array}{l}\text { Dromopus } \\
\text { lacertoides }\end{array}$ & Sauropsida \\
\hline H 6 & Ichnium aerodactylum & Not restudied & Not restudied & $\begin{array}{l}\text { Batrachichnus } \\
\text { salamandroides }\end{array}$ & $\begin{array}{l}\text { Temnospondyl } \\
\text { amphibian }\end{array}$ \\
\hline
\end{tabular}

4 
Table 2 (on next page)

Tetrapod ichnotaxa and their supposed trackmakers reported from Alveley (Tucker \& Smith, 2004) contrasted with those from Hamstead 
1 Table 2. Tetrapod ichnotaxa and their supposed trackmakers reported from Alveley (Tucker \& Smith,

2 2004) contrasted with those from Hamstead.

3

$\begin{array}{llcc}\text { Ichnospecies } & \text { Trackmaker } & \text { Alveley } & \text { Hamstead } \\ \text { Batrachichnus salamandroides } & \text { Temnospondyl amphibian } & \text { X } & \text { X } \\ \text { Dimetropus leisnerianus } & \text { Non-theraspid synapsid } & \text { X } & \text { X } \\ \text { Dromopus lactertoides } & \text { Sauropsida } & & \text { X } \\ \text { Hyloidichnus bifurcatus } & \text { Captorhinomorphs } & \text { X } & \\ \text { Ichniotherium willsi } & \text { Diadectomorphs } & \mathrm{X} & \\ \text { Limnopus isp. } & \text { Temnospondyl amphibian } & & \mathrm{X} \\ \text { Limnopus plainvillensis } & \text { Temnospondyl amphibian } & \mathrm{X} & \\ \text { Limnopus vagus } & \text { Temnospondyl amphibian } & \mathrm{X} & \end{array}$

4 